\title{
PENGEMBANGAN SMOKE EXHAUST MENGGUNAKAN ARDUINO UNO DAN SENSOR MQ-2 UNTUK MEMINIMALISIR ASAP BUANG DI RUANG PRAKTIK OTOMOTIF SMK MUHAMMADIYAH TASIKMALAYA
}

\author{
Dimas Sigit Nurfaizi ${ }^{1)}$, Cecep Riki'), Taofik Muhammad ${ }^{3)}$ \\ ${ }^{1,2,3)}$ Pendidikan Teknologi Informasi FKIP Universitas Muhammadiyah Tasikmalaya

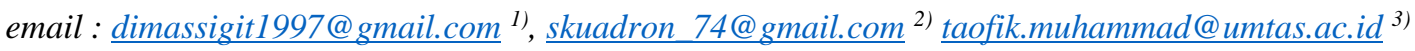

\begin{abstract}
ABSTRAKSI
Project Smoke Exhaust ini mempunyai peran yang cukup besar dalam menunjang proses praktikum otomotif, namun belum banyak guru menggunakan dalam praktik otomotif yang melibatkan mesin kendaraan dalam praktiknya. Penelitian ini merupakan penelitian pengembangan (Research and Development). Pengembangan sendiri dilakukan dengan cara melalui beberapa tahapan yaitu: 1) pengumpulan informasi, 2) perencanaan, 3) pengembangan produk, dan 4) validasi serta ujicoba. Project Smoke Exhaust kemudian divalidasi oleh ahli media. Setelah melalui tahap validasi, kemudian dilakukan revisi sesuai saran dari validator dan dilakukan ujicoba project, sehingga diperoleh Pengembangan Smoke Exhaust Menggunakan Arduino Uno dan Sensor MQ-2 Untuk Meminimalisir Asap Buang Di Ruang Praktik Otomotif SMK Muhammadiyah Tasikmalaya.
\end{abstract}

Kata Kunci : Smoke Exhaust, Sensor MQ-2, Arduno Uno.

\begin{abstract}
The Smoke Exhaust Project has a fairly large role in supporting the automotive practicum process, but not many teachers use it in automotive practice that involves vehicle engines in practice. This research is a research development (Research and Development). The development itself is carried out by means of several stages, namely: 1) information gathering, 2) planning, 3) product development, and 4) validation and testing. The Smoke Exhaust project is then validated by media experts. After going through the validation stage, a revision was made according to the advice of the validator and a trial project was carried out, in order to obtain Smoke Exhaust Development Using the Arduino Uno and the MQ-2 Sensor to Minimize Exhaust Smoke in the Automotive Practice Room of SMK Muhammadiyah Tasikmalaya.
\end{abstract}

Keywords: Smoke Exhaust, MQ-2 Sensor, Arduno Uno.

\section{PENDAHULUAN}

Sekolah Menengah Kejuruan (SMK) adalah tingkatan Pendidikan menengah, yang mana SMK memiliki keharusan untuk melahirkan dan menyiapkan tenaga siap kerja yang handal dan juga cekatan. Teknik Otomotif adalah salah satu program jurusan yang ada dihampir seluruh satuan Pendidikan tingkat Sekolah Menengah Kejuruan, tak terkecuali juga di SMK Muhammadiyah Tasikmalaya yang memiliki jurusan tersebut.

Teknik Otomotif adalah salah satu program jurusan yang ada dihampir seluruh satuan Pendidikan tingkat Sekolah Menengah Kejuruan, tak terkecuali juga di SMK Muhammadiyah Tasikmalaya yang memiliki jurusan tersebut. Namun di SMK Muhammadiyah Tasikmalaya siswa teknik otomotif tidak hanya diajarkan dan diberikan materi mengenai pelajaran-pelajaran pada umumnya yang terdapat di dalam ruangan kelas, akan tetapi peserta didik juga diberikan praktik seperti cara merakit mesin dan juga praktik tentang penyusunan system kelistrikan pada kendaraan bermotor di Bengkel Otomotif yang ada di SMK Muhammadiyah Tasikmalaya.

Saat ini Indeks Standar Kualitas udara yang dipergunakan secara resmi di Indonesia adalah Indek Standar Pencemar Udara (ISPU), hal ini sesuai dengan Keputusan Menteri Negara Lingkungan Hidup Nomor : KEP 45 / MENLH / 1997 Tentang Indeks Standar Pencemar Udara. kualitas udara sendiri digolongkan menjadi beberapa 
kategori mulai dari Baik, Sedang, Tidak sehat, Sangat tidak sehat, Sangat berbahaya, seperti yang terdapat di gambar berikut.

\begin{tabular}{|c|l}
\hline 0-50 & $\begin{array}{l}\text { GOOD } \\
\text { Air pollution poses little or no risk. }\end{array}$ \\
\hline 51-100 & $\begin{array}{l}\text { MODERATE } \\
\text { Health concern for people who are unusually } \\
\text { sensitive to air pollution. }\end{array}$ \\
\hline $101-150$ & $\begin{array}{l}\text { UNHEALTHY FOR SENSITIVE GROUPS } \\
\text { Sensitive groups, young children and the elderly, } \\
\text { may experience health effects. }\end{array}$ \\
\hline $151-200$ & $\begin{array}{l}\text { UNHEALTHY } \\
\text { Everyone may experience health effects; sensitive } \\
\text { groups may experience more serious health effects. }\end{array}$ \\
\hline 201-300 & $\begin{array}{l}\text { VERY UNHEALTHY } \\
\text { Health alert: everyone may experience more } \\
\text { serious health effects. }\end{array}$ \\
\hline $301-500$ & $\begin{array}{l}\text { HAZARDOUS } \\
\text { Health warnings of emergency conditions. The } \\
\text { entire population is more likely to be affected. }\end{array}$ \\
\hline
\end{tabular}

Gambar 1.Indeks Kualitas Udara menurut Keputusan Menteri Negara Lingkungan Hidup Nomor : KEP 45 / MENLH / 1997

Agar penelitian ini dapat dilakukan lebih focus dalam pelaksanaannya, sempurna, dan mendalam maka disini peneliti memandang permasalahan penelitian yang diangkat harus diperuncing variabelnya. Oleh sebab itu, peneliti membatasi diri hanya berkaitan dengan "penggunaan sensor yang dibahas didalam penelitian ini adalah sensor MQ-2" dan "modul Arduino digunakan sebagai Main Proccess dan pengolah data, kemudian Software Arduino IDE sebagai Software input program".

umusan masalah dalam penelitian ini adalah Bagaimana memanfaatkan Arduino dalam mendeteksi Asap? dan bagaimana membuat seperangkat alat pendeteksi kadar Asap dengan menggunakan sensor MQ-2 ?

Tujuan yang ingin dicapai dari penelitian yang dilakukan adalah sebagai berikut:

1. Memanfaatkan perkembangan teknologi dibidang mikrokontroler untuk dunia Pendidikan dalam hal ini digunakan untuk meminimalisir asap didalam ruangan praktik otomotif.

2. Sebagai bentuk pemanfaatan sensor MQ-2 dan Arduino kemudian merakitnya menjadi alat pendeteksi Asap.

Maka dari itu disini kita dapat memanfaatkan kegunaan dari Arduino yang merupakan perangkat elektronika yang berbasis mikrokontroler dan Sensor MQ-2 sebagai modul detektor,. Oleh karenanya dengan upaya pengembangan dari alat ini diharapkan mampu untuk mengurangi kadar Asap buang yang ditimbulkan dari mesin saat praktik diruangan tersebut, karena pada fakta dilapangan saat sedang praktik menggunakan mesin, udara didalam ruangan menjadi pengap efek dari asap mesin yang menyala dan ventilator bangunan yang tidak signifikan dalam regenerasi oksigen didalam karena sifat dari ventilasi bangunan masih bergantung kepada angin yang memiliki sifat alamiah.

\section{METODE PENELITIAN}

\section{A. Desain Penelitian}

Penelitian ini termasuk jenis penelitian dan pengembangan (research and development). Menurut Borg \& Gall [3] penelitian dan pengembangan adalah "educational Research and Development $(R n D)$ is a process used to develop and validate educational products.

1. Tahapan Penelitian

Penelitian ini menggunakan model pengembangan yang dikembangkan oleh Borg \& Gall. Tahap-tahap penelitian dan pengembangan menurut Borg \& Gall [3] terdiri atas sepuluh tahap yang diantaranya adalah:

a. Research and Information colletion (penelitian \& pengumpulan data)

b. Planning (perencanaan)

c. Develop Preliminary form of Product (Tahap pengembangan produk) 
d. Preliminary Field Testing (uji coba lapangan awal)

e. Main Product Revision (revisi hasil uji coba)

f. Main Field Testing (uji lapangan produk utama)

g. Operational Product Revision (revisi produk)

h. Operational Field Testing (uji kelayakan)

i. Final Product Revision (revisi produk final)

j. Disemination and Implementasi (Desiminasi dan implementasi)

Berdasarkan tahapan penelitian dan pengembangan yang dikembangkan oleh Borg \& Gall peneliti melakukan penyederhanaan dan pembatasan menjadi empat tahapan. Hal tersebut didasarkan pada pendapat Borg \& Gall (1983) [3] yang menyarankan dalam penelitian skripsi, tesis dan disertasi, penelitian dibatasi dalam skala kecil termasuk kemungkinan untuk membatasi langkah penelitian. Tahap penelitian dan pengembangan yang akan dilaksanakan sebagai berikut:

1. Tahap Pengumpulan Informasi

a) Melakukan tinjauan terhadap project yang akan dikerjakan nanti

b) Melakukan studi pustaka untuk mengumpulkan materi yang diperlukan

2. Tahap Perencanaan

a) Pembuatan instrumen penelitian.

3. Tahap Pengembangan Produk

a) Pembuatan Skema wiring project menggunakan aplikasi Proteus.

b) Penyusunan Hardware yang akan digunakan dalam project kali ini.

c) Perancangan Software yang akan di inputkan kedalam board Arduino.

4. Tahap validasi dan uji coba

Tahap validasi dan ujicoba ini terbagi menjadi 3 yang diantaranya adalah sebagai berikut :

a) Validasi oleh ahli media.

b) Revisi project

c) Hasil akhir

a) Perancangan Program

Dalam Proses tahapan penelitian ini dilakukan dalam beberapa tahapan proses yaitu sebagai berikut :

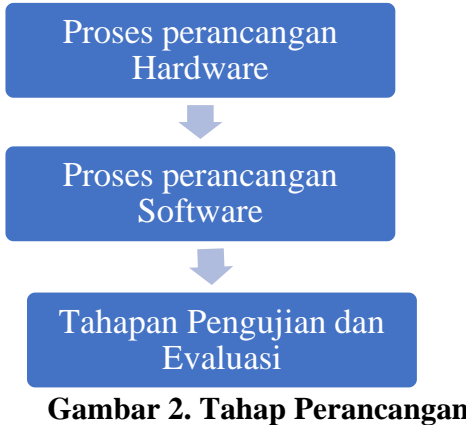

1) Tahapan perancangan hardware.

Tahapan ini berisi mengenai proses perancangan hardware :

- Siapkan modul modul yang diperlukan

- Lalu susun dan rangkai semua komponen dipapan Breadboard,

- Lalu lakukan cek ulang agar tidak ada trouble saat alat ditest.

2) Tahapan perancangan software.

Tahapan ini sendiri merupakan bagian dari tahapan perancangan yang berisikan mengenai proses perancangan software yang digunakan.

- Perancangan ini dilakukan dengan menuliskan listing program yang akan. 
- Software yang digunakan untuk melakukan Penelitian listing menggunakan Software Arduino Uno IDE.

- Pilih seri Arduino yang akan digunakan karena setiap Arduino memiliki struktur yang berbeda beda.

- Setelah listing ditulis lalu Upload listing program tersebut kedalam Arduino

3) Tahapan pengujian dan evaluasi.

Sedangkan tahapan pengujian dan evaluasi berfungsi untuk menjalankan ujicoba produk untuk mengetahui hasil dari 2 tahapan sebelumnya dan melihat evaluasi apa saja yang diperlukan

- Lakukan uji alat untuk mengetahui apakah alat berfungsi dengan baik atau terdapat kendala.

- Apabila alat terdapat masalah lakukan pengecekan kembali pada komponen apakah ada komponen yang lepas atau tidak terpasang dengan baik, lakukan juga pengecekan pada listing program apakah ada salah pengetikan listing program atau ada kesalahan pemilihan seri Arduino, pengecekan seri board atau port bisa dilakukan pada tab Tools $\rightarrow$ Board dan tab Tools $\rightarrow$ Port.

b) Perancangan Komponen

Hasil rancangan sistem secara keseluruhan dibagi menjadi beberapa bagian, seperti yang terlihat dalam grapik dibawah ini.

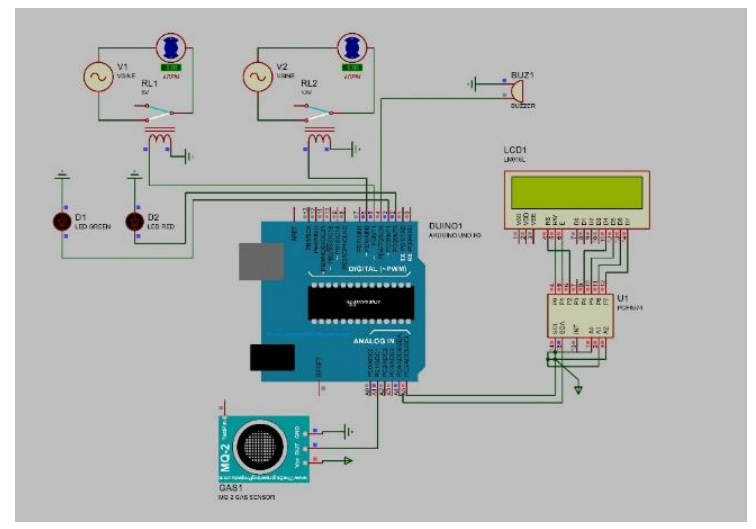

Gambar 3. Perancangan Sistem

Fungsi masing-masing blok dalam gambar 3.2 adalah sebagai berikut:

1) Modul Sensor Gas MQ-2 untuk mendeteksi konsentrasi asap Buang mesin yang terdapat di udara dan bagian output sensor merubahnya menjadi tegangan analog, Sensor dapat mengukur konsentrasi Asap.

2) Buzzer merupakan komponen yang dapat menghasilkan suara, yang dipasang pada salah satu pin output digital pada arduino, buzzer akan mengeluarkan suara pada saat sensor MQ-2 mendeksi asap dari mesin.

3) Arduino UNO yang berfungsi untuk mengolah data dari modul sensor MQ-2 dan mengakses buzzer untuk mengendalikan peralatan listrik (lampu, exhaust fan).

4) LED Merah berfungsi sebagai notifikasi atau pemberitahuan bahwa sensor mendeteksi adanya asap didalam ruangan praktik.

5) LED Hijau berfungsi sebagai notifikasi atau pemberitahuan bahwa exhaust telah meminimalisir asap didalam ruangan dengan membuangnya keluar.

6) LCD Display berperan sebagai layar pemberitahuan apakah didalam ruangan tersebut kadar asap sudah dalam keadaan normal atau belum.

7) Exhaust fan berperan sebagai media pembuang asap.

c) Perancangan Desain

Diagram Desain terdiri dari, masukan, bagian kendali, bagian keluaran. Pada bagian masukan berupa sebuah sensor MQ-2 yang berfungsi untuk menerima inputan yang terhubung dengan Arduino Uno sebagai pengolah data analog menjadi data digital pada bagian pengendali utama, pada bagian keluaran berupa Exhaust fan sebagai modul pembuang asap. 


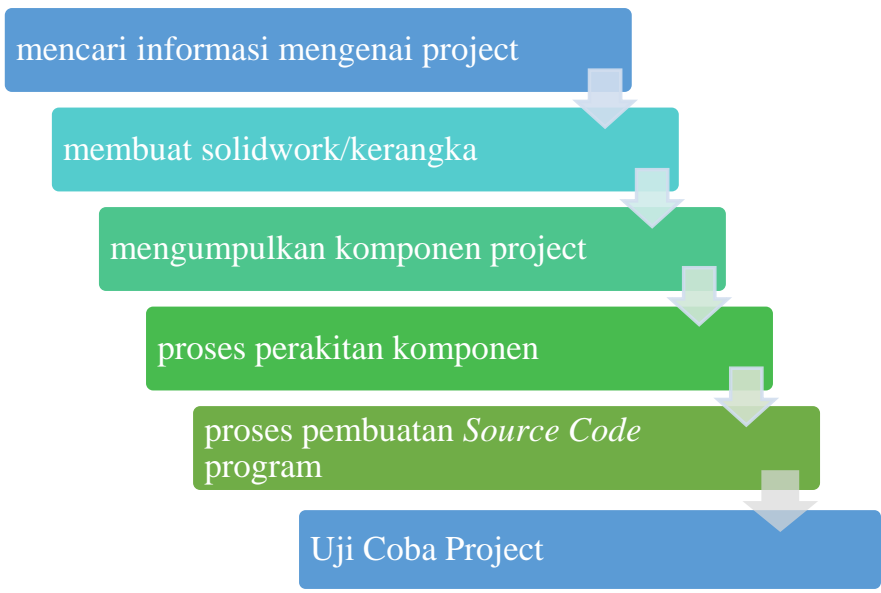

Gambar 4. Perancangan Desain

\section{d) Perancangan Software}

Tahapan proses yang terdapat pada sistem ini meliputi proses pengolahan data dari modul sensor MQ2 ke Arduino. Semua proses tersebut dilakukan oleh perangkat lunak yang terdapat dalam mikrokontroler. Perangkat lunak ini tersusun dari instruksi-instruksi yang membentuk sebuah listing program atau source-code. berikut adalah proses pembutan kode program dengan menggunakan Software Arduino IDE dan menggunakan Bahasa pemrograman C.

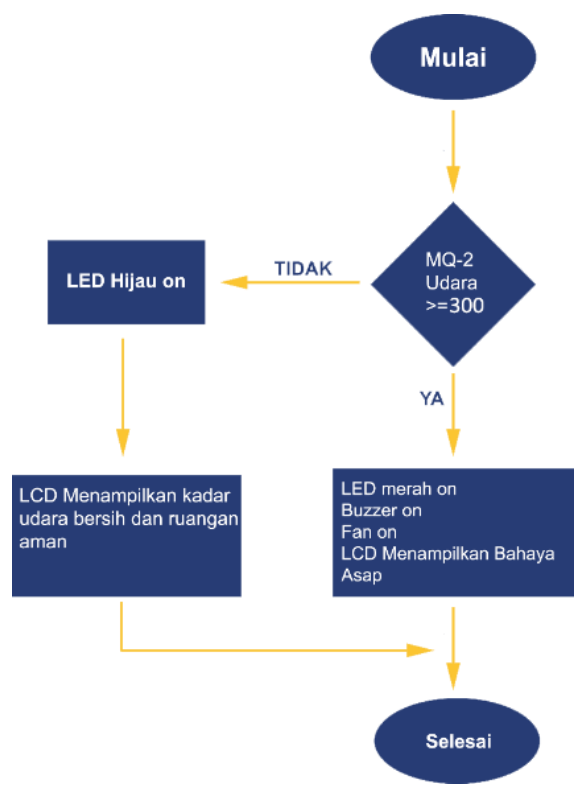

Gambar 5. Flow Chart

e) Data Kelayakan Produk

Data kelayakan produk yang dihasilkan, ditentukan dengan analisis hasil validasi ahli media, dan ujicoba penggunaan. Data hasil validasi dan ahli media dianalisis secara deskriptif. berikut Langkah analisisnya adalah sebagai berikut :

1) Mengubah penilaian yang sebelumnya bentuk kualitatif menjadi kuantitatif dengan ketentuan sebagai berikut : 
Table 1. Pedoman Penilaian Skor [6]

\begin{tabular}{|l|c|}
\hline \multicolumn{1}{|c|}{ Data Kualitatif } & Skor \\
\hline Sangat Baik (SB) & 5 \\
\hline Baik (B) & 4 \\
\hline Cukup (C) & 3 \\
\hline Kurang (K) & 2 \\
\hline Sangat Kurang (SK) & 1 \\
\hline
\end{tabular}

2) Mengubah penilaian yang sebelumnya memiliki bentuk kualitatif lalu diubah menjadi kuantitatif dengan ketentuan sebagai berikut :

$$
\bar{X}=\frac{\sum x}{N}
$$

Keterangan :

$$
\begin{array}{ll}
\bar{X} & =\text { rerata skor dari tiap komponen } \\
\sum_{N} x & =\text { jumlah skor } \\
& =\text { jumlah indikator yang dinilai }
\end{array}
$$

3) Mengubah skor rata-rata menjadi nilai kualitatif dengan kriteria sebagai berikut:

Table 2. Konversi Data Kuantitatif ke Kualitatif [7]

\begin{tabular}{|c|c|l|}
\hline Rentang Skor & Rerata & \multicolumn{1}{|c|}{ Kategori } \\
\hline $\boldsymbol{X}>\overline{\boldsymbol{X} \boldsymbol{l}}+\mathbf{1 . 8}$ & $X>4.2$ & Sangat Baik \\
\hline$\overline{\boldsymbol{X}}+\mathbf{0 . 6} \boldsymbol{s} \boldsymbol{b i} \leq \boldsymbol{X} \leq \overline{\boldsymbol{X}}+\mathbf{1 . 8} \boldsymbol{s b i}$ & $3.4<X \leq 4.2$ & Baik \\
\hline$\overline{\boldsymbol{X}}+\mathbf{0 . 6} \boldsymbol{s} \boldsymbol{b} i \leq \boldsymbol{X} \leq \overline{\boldsymbol{X} \boldsymbol{l}}+\mathbf{0 . 6} \boldsymbol{s b i}$ & $2.6<X \leq 3.4$ & Cukup \\
\hline$\overline{\boldsymbol{X} \boldsymbol{l}}+\mathbf{1 . 8} \boldsymbol{s} \boldsymbol{b i} \leq \boldsymbol{X} \leq \overline{\boldsymbol{X} \boldsymbol{l}}+\mathbf{0 . 6} \boldsymbol{s} \boldsymbol{b i}$ & $1.8<X \leq 2.6$ & Kurang \\
\hline $\boldsymbol{X} \leq-\mathbf{1 . 8} \boldsymbol{s} \boldsymbol{b} \boldsymbol{i}$ & $X \leq 1.8$ & Sangat Kurang \\
\hline
\end{tabular}

Keterangan :

$$
\begin{array}{lll}
\mathrm{X} & =\text { skor rata-rata } \\
\overline{\boldsymbol{X} \boldsymbol{l}} & & =\text { rata-rata ideal } \\
& & =\frac{1}{2}(\text { skor maksimal ideal }+ \text { skor minimal ideal }) \\
\mathrm{Sbi} & & =\text { simpangan baku } \\
& =\frac{1}{6}(\text { skor maksimal ideal }- \text { skor minimal ideal }) \\
\text { Skor maksimal ideal } & =\sum \quad \text { indikator } \mathrm{x} \text { skor tertinggi } \\
\text { Skor minimal ideal } & =\sum \quad \text { indikator } \mathrm{x} \text { skor terendah }
\end{array}
$$

Penilaian produk Smoke Exhaust Dengan Menggunakan Arduino Uno dalam penelitian dan pengembangan ini ditentukan dengan nilai minimal B, yaitu kategori baik. Jadi apabila rerata penilaian dari ahli media menunjukkan nilai B maka produk Smoke Exhaust Dengan Menggunakan Arduino Uno layak untuk kemudian di ujicobakan.

f) Perencanaan Implementasi

Prototype sendiri dibuat dengan skala 1:30 dari ruangan aslinya yaitu Panjang 33CM dan Lebar 13CM, sedangkan rencana implementasi produk ini sendiri adalah untuk diterapkan terhadap ruangan dengan luas Panjang 10m, dan Lebar 4m, menggunakan 2 komponen exhaust dengan ukuran 12 inch dimana 1 digunakan untuk keluaran dan 1 untuk masukan udara, dimana masing masing exhaust memiliki kecepatan rata - rata \pm 950 RPM dengan daya hisap dan daya buang sebesar 900M3/jam. dan menggunakan 2 buah sensor MQ-2 paralel yang ditempatkan di pelafon dari masing masing objek itu sendiri untuk memaksimalkan kinerja sensor dalam mendeteksi asap. 


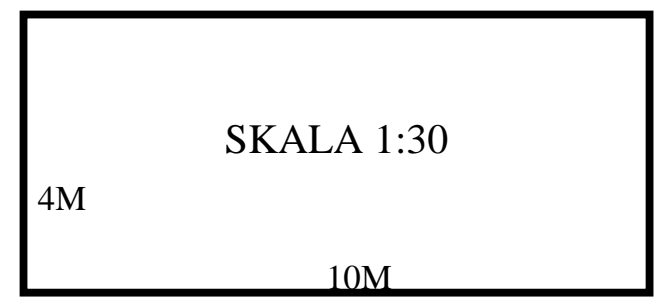

Gambar 6. Skala Ruangan

Untuk Desain penempatan sendiri disini terdapat dua buah opsi yang direkomendasikan, dimana untuk desain pertama adalah seperti gambar dibawah, dimana posisi kipas $e x$ dan in berada di sudut tembok depan dan belakang, sedangkan untuk desain kedua posisi kipas ex dan in berada ditembok samping kanan dan kiri nya

DESAIN 1

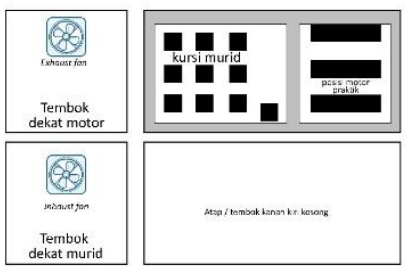

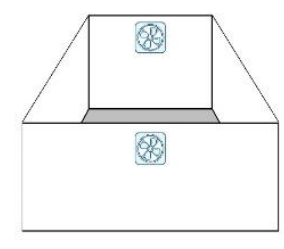

Gambar 7. Desain penempatan kipas
DESAIN 2

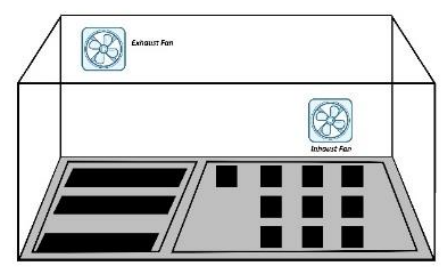

2. Jenis Data

Data yang dikumpulkan dalam penelitian ini adalah :

1. Data mengenai proses pengembangan smoke exhaust sesuai dengan prosedur pengembangan yang telah ditentukan.

2. Data mengenai kelayakan pengembangan Smoke Exhaust mencakup data data berikut:

a. Data kualitatif berupa nilai dari setiap kriteria penilaian yang dijabarkan menjadi 5 buah yaitu, sangat baik (SB), baik (B), cukup (C), kurang (K), dan sangat kurang (SK).

b. Data kuantitatif yang dia berupa skor penilaian $(\mathrm{SB}=5$, baik $=4$, cukup $=3$, kurang $=2$, sangat kurang $=$ 1). Data tersebut diperoleh dengan menghitung rata-rata (mean) skor setiap kriteria yang dihitung dari penilaian ahli media. Selanjutnya, skor ini dibandingkan dengan skor ideal untuk mengetahui kelayakan produk smoke exhaust.

c. Data kualitatif berupa hasil observasi saat produk dijalankan dan data hasil wawancara setelah produk di ujicobakan.

\section{Metode Pengumpulan Data}

Penelitian dan pengembangan ini menggunakan metode kuisioner atau angket dalam mengumpulkan data.

Berikut penjelasan dari metode Kuisioner atau angket :

1. Wawancara

Wawancara dilakukan untuk mengetahui tanggapan, komentar, dan saran tim otomotif setelah percobaan penggunaan smoke exhaust saat diberi beban asap. Metode wawancara dipilih karena peneliti dapat lebih dekat dengan narasumber sehingga informasi yang diperoleh lebih jelas. Wawancara dilakukan terhadap salah seorang dari tim otomotif SMK Muhammadiyah tasikmalaya.

2. Kuesioner

Kuesioner atau angket sendiri digunakan untuk mengetahui penilaian dari ahli media mengenai Pengembangan Smoke Exhaust Dengan Menggunakan Arduino Uno Untuk Meminimalisir Asap Buang Di Ruang Praktik Otomotif SMK Muhammadiyah Tasikmalaya.. Kuesioner yang digunakan dalam penelitian dan 
pengembangan ini adalah kuesinoer berstruktur dengan menggunakan skala Likert. Alternatif jawaban menurut skala Likert yaitu; sangat baik (SB), baik (B), cukup (C), kurang (K), dan sangat kurang (SK) (Sukardi, 2009:146).

\section{HASIL DAN PEMBAHASAN}

\section{A. Hasil Pengembangan}

Hasil dari pengembangan ini adalah sebuah produk Smoke Exhaust yang memanfaatkan Arduino Uno dan juga sensor MQ-2 sebagai modul utama dalam produk ini.

Belakang

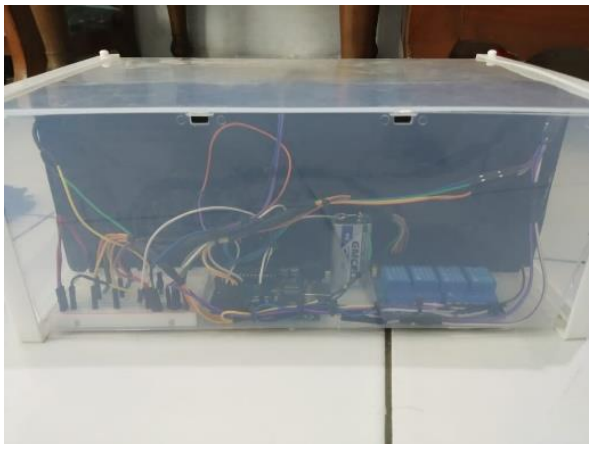

Depan

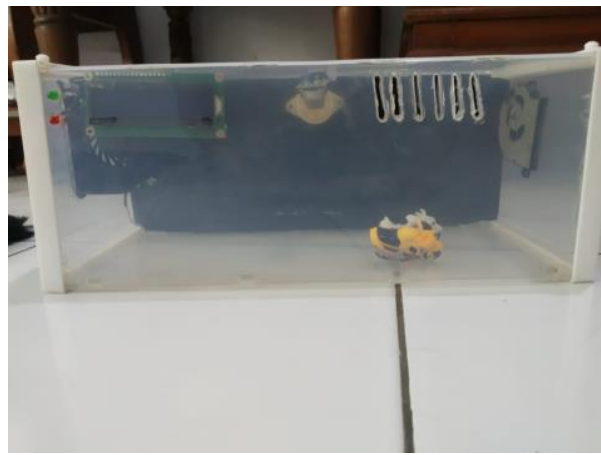

Gambar 8. Tampak depan belakang produk

Produk ini dibuat dengan tujuan awal untuk meminimalisir asap didalam ruangan praktik otomotif di SMK Muhammadiyah Kota Tasikmalaya, yang mana alat ini akan bekerja secara otomatis dalam mendeteksi asap didalam ruangan tersebut. Kesensitifan dari sensor nya sendiri dapat diatur dengan memutar kan potensiometer yang ada dibelakang modul sensor ke arah kanan atau kiri sesuai kondisi dilapangan dan kebutuhan dari lokasinya.

\section{B. Pembahasan}

Hasil penelitian dan pengembangan ini adalah produk Pengembangan Smoke Exhaust Dengan Menggunakan Arduino Uno Untuk Meminimalisir Asap Buang Di Ruang Praktik Otomotif SMK Muhammadiyah Tasikmalaya. Penelitian dan pengembangan ini dilaksanakan dengan mengacu pada tahapan penelitian dan pengembangan menurut Borg \& Gall. Borg \& Gall [3] ada sepuluh tahap dalam penelitian dan pengembangan, namun dalam penelitian dan pengembangan ini kesepuluh langkah tersebut disederhanakan menjadi empat langkah. Adapun factor faktor yang mendasari penyederhaan tersebut yaitu:

a) Keterbatasan waktu

Apabila penelitian dan jugapengembangan dari project ini dilakukan dengan menggunakan sepuluh tahapan akan menghabiskan waktu dan proses yang tergolong tidak sebentar. Oleh karena itu, melalui penyederhanaan menjadi empat tahapan penelitian.

b) Keterbatasan biaya

Biaya yang relatif membumbung tinggi akan diperlukan jika penelitian ini dilakukan dalam s;otjepuluh tahapan. Oleh karena itu, melalui penyederhanaan sedemikian rupa.

c) Kesamaan tahapan

Berdasarkan dari sepuluh tahap penelitian dan pengembangan dari model Borg \& Gall, ada beberapa tahap yang diantaranya memiliki kesamaan tujuan. Kesamaan tersebut dapat dilihat di beberapa tahapan, seperti pada tahap ujicoba lapangan awal, tahap ujicoba, dan tahap ujicoba pelaksanaan lapangan. Terdapatnya persamaan di beberapa tahapan ujicoba tersebut, membuat peneliti kemudian menyederhanakan menjadi satu tahapan ujicoba.

d) Tahap validasi dan ujicoba

Produk awal ditahap selanjutnya divalidasi oleh ahli media. Ahli media melakukan validasi sebanyak satu kali, hal ini sendiri dikarenakan perolehan rerata skor dari hasil validasi media menunjukkan 
nilai 3.7 yang termasuk kategori baik sehingga produk smoke exhaust sudah memenuhi standar untuk diuji cobakan. ujicoba sendiri dilakukan dengan cara memberikan masukan asap kedalam kotak, lalu sensor akan mendeteksi secara otomatis kadar asap yang masuk kedalam kotak dan akan menampilkan kadar asapnya melalui LCD, apabila asap >=300 maka LED Hijau mati, LED Merah, buzzer dan Kipas menyala, apabila asap dibawah >=300 maka LED Merah, huzzer dan Kipas mati lalu LED Hijau Menyala.

\section{KESIMPULAN}

Dari hasil penelitian dan pembahasan tentang Pengembangan Smoke Exhaust Menggunakan Arduino Uno dan Sensor MQ-2 Untuk Meminimalisir Asap Buang Di Ruang Praktik Otomotif SMK Muhammadiyah Tasikmalaya yang telah di ejawantahkan maka kemudian dapat ditarik kesimpulan sebagai berikut :

1. Penelitian dan pengembangan ini menghasilkan produk berupa Pengembangan Smoke Exhaust Menggunakan Arduino Uno dan Sensor MQ-2 Untuk Meminimalisir Asap Buang Di Ruang Praktik Otomotif SMK Muhammadiyah Tasikmalaya.

2. Berdasarkan dari hasil ujicoba produk smoke exhaust dengan menggunakan sensor MQ-2 sebagai modul inputan, sensor dapat bekerja dengan semestinya dan sesuai program yang sudah di inputkan kedalam arduino, dimana apabila sensor mendeteksi asap >=300 maka sensor akan mengirim sinyal menuju arduino untuk menyalakan komponen output.

3. Produk Smoke Exhaust yang dibuat berhasil meminimalisir asap yang berada didalam box dengan baik, karena menggunakan dua buah kipas, dimana satu kipas sebagai exhaust dan satu kipas sebagai inhaust yang membuat sirkulasi udara didalam box cepat terganti dengan udara baru

\section{Saran}

Berdasarkan hasil penelitian dan pengembangan ini, maka dapat disarankan hal-hal sebagai berikut:

1. Bagi pembaca, hasil penelitian ini diharapkan dapat menambah wawasan pengetahuan terkait dengan microcontroller dan juga sensor.

2. Project smoke exhaust hasil diharapkan dapat digunakan dalam dunia Pendidikan khususnya di ruangan praktik otomotif karena dapat meminimalisir kandungan asap yang berada didalam ruangan saat asap berada $\geq 300 \mathrm{ppm}$.

3. Perlunya dilakukan pengembangan dalam komponen yang digunakan, seperti komponen project board, kabel jumper, dan kipas yang digunakan untuk meningkatkan kualitas.

\section{DAFTAR PUSTAKA}

[1]. Polusi Ruangan Menggunakan Sensor Asap Dengan Pemberitahuan Melalui Sms (Short Message Service) Dan Alarm Berbasis Arduino, Jurnal Ilmiah Teknologi dan Informasia ASIA (JITIKA) Vol.10, Malang.

[2]. Borg, W.R. \& Gall, M.D. Gall. Educational Research: An Introduction,. Fifth Edition. New York: Longman. 1983.

[3]. Asap Detection Using Arduino, International Journal of Science Technology \& Engineering (IJSTE) Volume 2, Nagpur

[4]. Heri Andrianto, Aan Darmawan., Arduino Belajar Cepat Dan Pemrograman, Informatika, Bandung: 2016

[5]. Sugiyono. 2012. Metode Penelitian Kuantitatif Kualitatif dan R\&D. Bandung: Alfabeta. Prof.H. Rozali Abdulah, S.H.2005.

[6]. Sukardi, Metodologi, Penelitian Pendidikan: kompetensi dan. Praktiknya.Jakarta: Bumi Aksara. 2011.

[7]. Widoyoko, E. P. (2009). Evaluasi program pembelajaran. Yogyakarta: pustaka pelajar, 238.

[8]. Ikhsan, I. (2017). Implementasi Arduino Dalam Rancang Bangun Alat Uji Emisi Kendaraan Bermotor Berbasis Android. Jurnal Ilmu Komputer, 6(1), 1-7.

[9]. Sujatmoko, A. S. R., Waworundeng, J., \& Wahyudi, A. K. (2015). Rancang Bangun Detektor Asap Rokok Menggunakan SMS Gateway Untuk Asrama Crystal di Universitas Klabat. Proceedings Konferensi Nasional Sistem dan Informatika (KNS\&I)

[10]. Kinanti, V. N., Yamin, M., \& Aksara, L. F. (2016). Prototype Penyaring Asap Rokok Pada Smoking Area Menggunakan Pulse Width Modulation (PWM) Dan Fuzzy Tsukamoto. semanTIK, 2(1). 
[11]. Mutaqin, A. (2018). Perancangan Alat Pendeteksi Kebocoran Gas Berbasis

[12]. Mikrokontroler Arduino Yang Terintegrasi Dengan Smartphone (Doctoral dissertation, President University)

\section{Biodata Penulis}

Dimas Sigit Nurfaizi, Dilahirkan di Kabupaten Sragen tepatnya di Dusun pilangsari Kecamatan Ngerampal pada hari Rabu tanggal 29 Oktober 1997. Anak ketiga dari tiga bersaudara pasangan dari Ibu Rohayati dan Bapak Maridi Prihantoro. Peneliti menyelesaikan pendidikan di Sekolah Dasar di SD Karsanagara Kecamatan Kawalu Kota Tasikmalaya pada tahun 2009. Pada tahun itu juga peneliti melanjutkan Pendidikan di SMP Negeri 12 Kota Tasikmalaya Kecamatan Kawalu dan tamat pada tahun 2013 kemudian melanjutkan Sekolah Menengah Kejuruan di SMK Muhammadiyah Kota Tasikmalaya pada tahun 2013 dan seslesai pada tahun 2016. Pada tahun 2016 peneliti melanjutkan pendidikan di perguruan tinggi Swasta Muhammadiyah, tepatnya di Universitas Muhammadiyah Tasikmalaya (UMTAS) Fakultas Keguruan dan Ilmu Pendidikan pada Program Studi Pendidikan Teknologi Informasi (PTI). dan terhitung saat ini peneliti sedang menyelesaikan Pendidikan tingginya. 